\title{
Pengaruh Profitabilitas dan Likuiditas terhadap Struktur Modal pada Perusahaan Retail Trade yang Terdaftar di BEI
}

\author{
Alviyah Ramadani ${ }^{1 *}$, Wayan Cipta ${ }^{2}$ \\ ${ }^{123}$ Program Studi Manajemen, Fakultas Ekonomi, Universitas Pendidikan Ganesha, Singaraja, Indonesia \\ *alviyahramadani14@gmail.com ${ }^{{ }^{*}}$
}

\section{Abstrak}

Penelitian ini bertujuan untuk menguji pengaruh: (1) Profitabilitas dan Likuiditas terhadap Struktur Modal, (2) Profitabilitas terhadap Struktur Modal, (3) Likuiditas terhadap Struktur Modal pada perusahaan Retail Trade yang terdaftar di Bursa Efek Indonesia. Desain penelitian ini menggunakan hubungan sebab akibat. Subjek yang digunakan dalam penelitian ini adalah perusahaan retail trade yang terdaftar di Bursa Efek Indonesia, dan objek penelitian ini adalah profitabilitas, likuiditas dan struktur modal. Populasi pada perusahaan Retail Trade yang terdaftar di Bursa Efek Indonesia sebanyak 25 perusahaan dan yang menyampaikan laporan perusahaan sebanyak 22 perusahaan. Data dikumpulkan dengan pencatatan dokumen, kemudian dianalisis dengan analisis regresi liniear berganda. Hasil penelitian menunjukkan bahwa: (1) Profitabilitas dan Likuiditas berpengaruh signifikan terhadap Struktur Modal dengan sumbanga senesar 75,7\%, (2) Profitabilitas berpengaruh negatif signifikan terhadap Struktur Modal sebesar 9,9\%, (3) Likuiditas berpengaruh negatif signifikan terhadap Struktur Modal sebesar $19,4 \%$.

Kata Kunci: Likuiditas, Profitabilitas, Struktur Modal

\section{Abstract}

This study aimed at examinizing the effect of: (1) The Profitability and Liquidity on Capital Structure, (2) The Profitability on Capital Structure, (3) The Liquidity on Capital Structure in Retail Trade companies listed in Indonesian Stock Exchange. The research design uses a causal and effect relationship. The subjects used in this study were Retail Trade companies has listed in Indonesian Stock Exchange. The object of this study was profitability, liquidity and capital structure. The population of Retail Trade companies listed on the Indonesia Stock Exchange is 25 companies and those who submit the reports are 22 companies. The data collected by document recording, then analyzed by multiple linear regression analysis. The results of this study showed that: (1) Profitability and Liquidity had a significant effect on the Capital Structure with a contribution, (2) Profitability had a significant negative effect to the Capital Structure, (3) Liquidity had a significant negative effect on the Capital Structure

Keywords: Liquidity, Profitability, Capital Structure

\section{Pendahuluan}

Pesatnya kemajuan sebuah teknologi menyebabkan tingginya angka persaingan antar perusahaan. Perusahaan perlu memperluas jaringannya serta meningkatkan taktik perusahaannya. Dalam era saat ini tidak bisa dipungkiri adanya persaingan baik dalam skala nasional maupun skala internasional. Begitu juga pada perusahaan-perusahaan yang tergabung kedalam Bursa Efek Indonesia (BEI). BEI mencatat lebih dari seratus perusahaan yang termasuk ke dalam sektor perdagangan, jasa dan investasi. Salah satu sub sektor yang termasuk dalam sektor perdagangan, jasa dan investasi adalah sub sektor perdagangan eceran.

Perdagangan Eceran atau disebut pula ritel trade merupakan keseluruhan sebuah kegiatan yang secara langsung melibatkan dua pihak untuk keperluan pribadi. Perkembangan ritel modern di Indonesia sejak tahun 2000 berkembang dengan sangat tinggi dan dengan tidak langsung membentuk sebuah pola pada industri ritel trade di Indonesia. Dalam

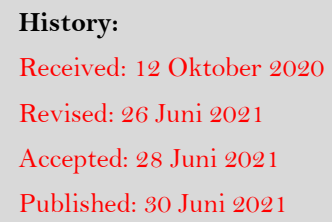


perkembangannya, banyak perusahaan-perusahaan baru yang muncul untuk bersaing dengan perusahaan yang sudah ada. Bahkan perusahaan-perusahaan baru dapat menguasai pangsa pasar. Selain itu, persaingan didalam dunia bisnis menuntut perusahaan agar mampu meningkatkan dan mempertahankan pendanaan didalam perusahaan tersebut.

Informasi pendanaan atau permodalan diperlukan untuk menilai kondisi perusahaan dimasa depan dalam memaksimalkan kesejahteraan pemilik dengan meningkatkan nilai perusahaan. Struktur modal pada perusahaan merupakan pembelanjaan permanen yang mencerminkan perusahaan dengan modal sendiri yang berupa laba ditahan dan penerbitan saham. Semakin besar struktur modal didalam suatu perusahaan berarti semakin besar tingkat pengembalian biaya utang melalui modal yang dimilikinya dan semakin tinggi risiko yang dihadapi oleh perusahaan.

Profitabilitas dalam kaitannya dengan struktur modal dapat memberikan sebuah keuntungan melalui berbagai efektivitas perusahaan. Dahlena (2017) dalam penelitiannya menyatakan bahwa, profitablitas dapat memperlihatkan sebuah kekuatan perusahaan untuk mendapatkan keuntungan tinggi dalam kurun waktu tertentu.

Likuiditas digunakan untuk menggambarkan suatu kekuatan bagi perusahaan dalam melunasi hutang yang akan segera jatuh tempo dalam jangka waktu pendek. Adiguna dan Sampurno (2017) dalam penelitiannya menyatakan bahwa, likuiditas dapat menunjukkan kekuatan sebuah usaha dalam melunasi utang jangka pendeknya dengan menggunakan aktiva lancar perusahaan.

Penelitian ini dilakukan di perusahaan retail trade yang terdaftar di Bursa Efek Indonesia. Pemilihan perusahaan retail trade karena perusahaan ini merupakan perusahaan yang bergerak dibidang perdagangan yang menjual barang dagangan secara langsung kepada konsumen akhir, dimana perusahaan ini yang paling menarik pada masa ini, karena akan terus ada dan berkembang seiring dengan pertumbuhan jumlah penduduk. Perkembangan perusahaan retail trade ini sangat baik memberikan keuntungan bagi perusahaan untuk tetap mengembangkan usahanya dan menarik perhatian investor dalam berinvestasi. Selain itu, perusahaan perdagangan eceran ini memiliki beberapa permasalahan nilai struktur modal yang berfluktuasi. Struktur modal yang berfluktuasi menggambarkan rasio utang yang tidak konsisten sehingga akan mengakibatkan ancaman bagi perusahaan dan berdampak pada minat investor untuk berinvestasi. Perusahaan juga akan sulit untuk mendapatkan modal dari pihak eksternal jika dana yang digunakan lebih besar menggunakan utang maka nantinya akan menghambat produktivitas perusahaan sehingga perusahaan mengalami kebangkrutan.

Struktur modal pada penelitian ini diukur dengan Debt to Equity Ratio (DER). Debt to Equity Ratio (DER) adalah rasio perbandingan antara hutang dengan ekuitas, atau sebuah kondisi dimana perusahaan dengan sangat mampu memenuhi seluruh beban perusahaan menggunakan modal dari perusahaan itu sendiri. Profitabilitas pada penelitian ini diukur dengan return on assets (ROA) merupakan Rasio yang mengukur kemampuan perusahaan menghasilkan laba bersih berdasarkan tingkat aktiva. Sedangkan likuiditas diukur dengan Current Ratio (CR) merupakan ukuran untuk mengukur kemampuan perusahaan dalam memenuhi kewajibannya. Dalam penelitian awal didapatkan hasil mengenai struktur modal. Dalam penelitian awal didapatkan hasil mengenai struktur modal, profitabilitas dan likuiditas pada perusahaan retail trade di Bursa Efek Indonesia seperti tampak pada lampiran 01. Berdasarkan pengamatan pada Perusahaan retail trade, diperoleh data profitabilitas, likuiditas dan struktur modal seperti nampak pada Tabel 1.

Tabel 1. Data profitabilitas (ROA), likuiditas (CR) dan struktur modal (DER) pada Perusahaan retail trade yang terdaftar pada Bursa Efek Indonesia tahun 2017 2018 


\begin{tabular}{|c|c|c|c|}
\hline Nama Perusahan & $\begin{array}{c}\text { ROA } \\
(\%)\end{array}$ & $\begin{array}{l}\text { CR } \\
(\%) \\
\end{array}$ & $\begin{array}{c}\text { DER } \\
(\%)\end{array}$ \\
\hline Mitra Adiperkasa Tbk. & $-0,14$ & $-0,01$ & 2,3 \\
\hline Sumber Alfaria Trijaya Tbk. & $-13,67$ & $-11,21$ & $-4,81$ \\
\hline Catur Sentosa Adiprana Tbk. & $-6,96$ & $-5,12$ & $-6,9$ \\
\hline
\end{tabular}

Berdasarkan Tabel 1. menunjukkan bahwa terjadi penurunan ROA pada perusahaan Mitra Adiperkasa Tbk, pada tahun 2017 - 2018 sebesar 0,14\% dan terjadi peningkatan DER sebesar 2,3\%. Kemudian pada perusahaan Sumber Alfaria Trijaya Tbk, pada tahun 2017 2018 mengalami penurunan ROA sebesar 13,67\% dan terjadi penurunan pada DER sebesar 4,81\%. Kemudian pada perusahaan Catur Sentosa Adiprana Tbk, mengalami penurunan ROA pada tahun 2017 - 2018 sebesar 6,96\% dan mengalami penurunan pada DER sebesar $6,9 \%$. Berdasarkan data yang telah dipaparkan pada ketiga perusahaan diatas, terjadi ketidaksesuaian data dengan teori yang ada. Brigham dan Houston (2006: 43), Menyatakan sebuah Perusahaan yang mempunyai sebuah tingkat pengembalian tinggi akan mempergunakan utang yang relatif sedikit. Perusahaan yang memiliki profitabilitas tinggi tidak perlu menggunakan dana eksternal karena dari laba yang tinggi tersebut perusahaan dapat membiayai operasional perusahaannya.

Perusahaan Mitra Adiperkasa Tbk, pada tahun 2017 - 2018 mengalami penurunan CR sebesar 0,01\% dan terjadi peningkatan DER 2,3\%. Kemudian pada tahun $2017-2018$ perusahaan Sumber Alfaria Trijaya Tbk, mengalami penurunan CR sebesar 11,21\% dan penurunan DER sebesar 4,81\%. Dan yang terakhir pada perusahaan Catur Sentosa Adiprana Tbk, mengalami penurunan CR pada tahun 2017 - 2018 sebesar 5,12\% dan mengalami penurunan DER sebesar 6,7\%. Berdasarkan data yang telah dipaparkan pada ketiga perusahaan diatas, terjadi ketidaksesuaian data dengan teori yang ada. Menurut Kasmir (2010: 110) bahwa Rasio likuiditas yang tinggi akan diikuti dengan utang yang rendah disebabkan oleh aktiva lancar pada perusahaan nantinya dapat memenuhi seluruh utang jangka pendek. Sebuah perusahaan yang mempunyai tingkat utang tinggi diartikan bahwa perusahaan tersebut mempunyai tingkat pendanaan yang baik sehingga perusahaan akan lebih memilih mempergunakan modal sendiri untuk membiayai investasi dan kegiatan operasionalnya sebelum menggunakan dana eksternal berupa utang.

Berdasarkan latar belakang penelitian di atas, penulis tertarik untuk mengambil judul penelitian yaitu: "Pengaruh Profitabilitas dan Likuiditas Terhadap Struktur Modal Pada Perusahaan retail trade yang terdaftar di Bursa Efek Indonesia". Penelitian ini menggunakan data tahun 2017 - 2018.

Merujuk pada latar belakang yang sudah dipaparkan, rumusan masalah yang disampaikaniyakni:i(1)Lapakah adai pengaruh profitabilitas dan likuiditas terhadap struktur modal pada Perusahaan retail trade yang terdaftar di Bursa Efek Indonesia?i(2)Lapakah ada pengaruhi profitabilitas terhadap struktur modal pada Perusahaan retail trade yang terdaftar di Bursa Efek Indonesia? (3) apakah adak pengaruh likuiditas terhadap struktur moda pada Perusahaan retail trade yang terdaftar di Bursa Efek Indonesia?.

Merujuk pada rumusan masalah, tujuan penelitian ini untuk menguji pengaruh:(1) Profitabilitas dan likuiditas terhadap struktur modal pada Perusahaan retail trade yang terdaftar di Bursa Efek Indonesia.i(2)LProfitabilitas terhadap struktur modal pada Perusahaan retail trade yang terdaftar di Bursa Efek Indonesia.i(3)L Likuiditas terhadap struktur moda pada Perusahaan retail trade yang terdaftar di Bursa Efek Indonesia.

\section{Struktur Modal}

Struktur modal merupakan sebuah gabungan antara hutang dengan modal sendiri, dimana menjadi sumber pembiayaan suatu perusahaan (Riyanto, 2011; 22). Brigham dan Houston (2011), menyatakan bahwa sebuah struktur modal yang optimum merupakan 
struktur yang memaksimalkan harga dari saham perusahaan. Oleh karena itu, perusahaan dalam membentuk sebuah struktur modal haruslah tidak bersifat kaku namun harus sesuai dengan kondisi perusahaan.

Struktur modal dalam penelitian ini diukur dengan Debt to Equity Ratio (DER). DER memperlihatkan sebuah perbandingan antara utang dan ekuitas dalam sebuah pendanaan suatu perusahaan dan menunjukkan kemampuan modal sendiri sebuah perusahaan dalam memenuhi seluruh kewajibannya, semakin tinggi DER maka semakin rendah pendanaan perusahaan yang disediakan oleh pemegang saham. Menurut Kasmir (2010: 124) DER dapat dirumuskan sebagai berikut.

$$
\text { Debt to equity ratio }=\frac{\text { Total utang }}{\text { Ekuitas }} \times 100 \%
$$

Indikator struktur modal: Struktur modal dalam penelitian ini diukur dengan debt to equity ratio komponen indikator debt to equity ratio yaitu:

1. Total utang (debt) : kewajiban yang harus dibayar oleh perusahaan dimasa yang akan datang yang berupa uang atau jasa. Menurut Jusuf (2011: 29) Total utang merupakan kewajiban yang harus dilunasi pihak peminjam menggunakan segala hal.

2. Ekuitas (equity) : sumber pendanaan yang bersumber atau diperoleh dari pemilik perusahaan atas kekayaan. Menurut Jusuf (2011) "Ekuitas merupakan hak pemilik perusahaan atas kekayaan (aset perusahaan), besarnya hak pemilik sama dengan aset bersih perusahaan".

\section{Profitabilitas}

Profitabilitas adalah kesanggupan sebuah usaha dalam mendapatkan laba dan memberikan tingkat efektivitas manajemen perusahaan yang akan ditunjukkan dari keuntunga bersih yang didapatkan serta berkaitan dengan penjualan, asset atau modal. Profitabilitas adalah sebuah rasio yang dipergunakan untuk menilai keterampilan usaha dalam mendapatkan laba (Kasmir, 2010: 115). Menurut Hanafi (2014: 91) profitabilitas adalah sebuah rasio yang dipergunakan untuk menilai kemampuan perusahaan dalam menghasilkan laba pada tingkat penjualan, aset, dan modal saham yang tertentu.

Profitabilitas pada penelitian ini diukur menggunakan rasio Return on Assets (ROA).

Rasio ini dapat digunakan perusahaan untuk mengukur tingkat efektivitas aktivanya dalam kegiatan operasional. ROA dapat dirumuskan sebagai berikut Fahmi (2011: 137).

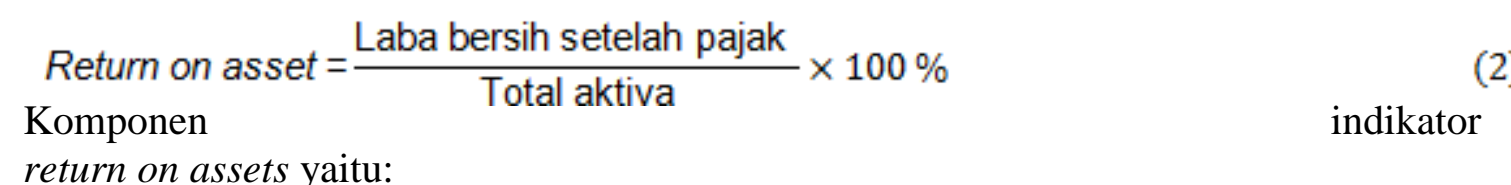

1. Laba Setelah Pajak (EAT)

Menurut Fahmi (2011: 101) EAT merupakan laba yang didapatkan setelah dikurangi dengan biaya lainnya seperti pajak.

2. Total Aktiva

Menurut Kodrat dan Kurniawan (2010:189) Total aktiva adalah investasi yang nantinya akan memberikan sebuah keuntungan melalui sebuah kegiatan operasi.

\section{Likuiditas}

Menurut Hanafi (2014: 75) likuiditas merupakan Rasio yang menilai sebuah kesanggupan likuiditas jangka pendek perusahaan dengan melihat aktiva lancar perusahaan relatif terhadap utang lancar (utang dalam hal ini merupakan kewajiban perusahaan). Likuiditas pada penelitian ini dapat diukur dengan menggunakan current ratio (CR). Menurut 
Kasmir (2010: 111) CR digunakan untuk menilai kesanggupan usaha dalam melunasi utang jangka pendek saat ditagih secara menyeluruh. Menurut Kasmir (2010: 119) CR dapat dirumuskan sebagai berikut.

Current ratio $=\frac{\text { Aktiva lancar }}{\text { Hutang lancar }} \times 100 \%$

Komponen indikator current ratio yaitu:

1. Aktiva Lancar

Aktiva lancar adalah keseluruhan kekayaan perusahaan dimana nantinya dapat diuangkan dalam periode singkat (Kasmir, 2013:134).

2. Utang Lancar

Menurut Kasmir (2013: 134) Utang lancar adalah sebuah kewajiban dari pihak perusahaan dengan periode waktu yang singkat dimana kewajiban tersebut harus diselesaikan dalam satu tahun.

\section{Hubungan ProfitabilitasldanlLikuiditaslterhadaplStruktur Modal}

Struktur modal merupakan cerminan dari baik tidaknya keadaan keuangan didalam sebuah perusahaan, sehingga struktur modal sangat dibutuhkan dalam meningkatkan suatu kegiatan operasional perusahaan untuk menilai keadaan perusahaan. Dalam hal ini penyusunan struktur modal menyesuaikan dengan kondisi perusahaan, apakah utang perusahaan dalam kondisi yang menyebabkan perusahaan mengalami kekurangan pendanaan atau kondisi profit perusahaan yang sedang dalam keadaan yang sangat baik.

Myers (1984) mengatakan perusahaan yang memiliki laba yang tinggi justru memilikii tingkat hutang yang lebih kecil, hal ini disebabkan karena pihak perusahaan yang memilikii tingkat keuntungan yang tinggi cenderung memiliki sumber dana internal yang besar untuk mendanai suatu perusahaan. Hal ini didukung oleh penelitian yang dilakukan oleh Wicaksono (2017).

\section{$H_{1}$ : Profitabilitasidanilikuiditas secara bersamaan mempengaruhi terhadap struktur modal}

\section{Hubungan ProfitabilitaslterhadaplStruktur Modal}

Brigham dan Houston (2006: 43), menyatakan bahwa perusahaan yang memiliki tingkat pengembalian atas investasi yang sangat tinggi menggunakan utang yang relatif sedikit. Perusahaan dengan tingkat keuntungan yang tinggi tidak perlu mempergunakan dana lainnya, karena dari keuntungan itu pihak perusahaan dapat membiayai operasional perusahaannya. Sehingga semakin tinggi tingkat profitabilitas perusahaan maka semakin besar pula tersedianya dana internal untuk investasi sehingga penggunaan utang relatif lebih kecil. Hal ini sejalan dengan penelitian yang dilakukan oleh Deviani dan Sudjarni (2018) dan penelitian yang dilakukan oleh Pertiwi dan Darmayanti (2018).

$\mathrm{H}_{2}$ : Profitabilitas berpengaruh negatifl terhadap struktur modal

\section{Hubungan Likuiditas terhadap Struktur Modal}

Kasmir (2010: 110) menyatakan bahwa Rasio likuiditas yang tinggi akan diikuti dengan utang yang rendah karena ketersediaan aktiva lancar nantinya akan membiayai seluruh kewajiban jangka pendek. Perusahaan dengan tingkat likuiditas yang tinggi berarti mempunyai tingkat pendanaan yang tinggi pula, sehingga perusahaan akan lebih memilih menggunakan dana pribadinya untuk membiayai investasi dan kegiatan operasionalnya sebelum menggunakan dana eksternal berupa utang. Hal ini sejalan dengan penelitian yang dilakukan Watung (2016) dan Eviani (2015). 


\section{H3: Likuiditas berpengaruh negative terhadap struktur modal}

\section{Metode}

Penelitian ini menggunakan desain penelitian hubungan sebab akibat. Hubungan sebab akibat ini digunakan untuk mengkaji hubungan sebab akibat antara variabel independent dan variabel dependent. Variabel bebas (independent) yang digunakan dalam penelitian ini meliputi: profitabilitas (X1), dan likuiditas (X2). Sedangkan variabel terikat (dependent) yang digunakan adalah struktur modal (Y). Populasi pada penelitian ini yaitu perusahaan retail trade yang terdaftar di BEI, dengan jumlah populasi sebanyak 25 perusahaan dan yang menyampaikan laporan perusahaan sebanyak 22 perusahaan yang terdaftar di BEI dari tahun 2017 - 2018, sehingga jumlah sampel yang digunakan dalam penelitian ini adalah 22 perusahaan. Dalam penelitian ini penganalisa data dengan menggunakan rumus-rumus statistik yaitu analisis regresi berganda dimana pengolahan data menggunakan program SPPS for Windows versi 22.0. Data dianalisis dengan menggunakan analisis regresi linier berganda karena berdasarkan paradigma yang dibangun tidak ada keterkaitan atau korelasi antar variabel bebas. Sebelum itu dilakukan pengujian menggunakan uji asumsi klasik. Uji asumsi kelasik meliputi: (1) uji normalitas, (2) multikolinearitas, (3) uji heteroskedastisitas serta (4) uji autokorelasi.

\section{Hasil dan Pembahasan}

Model analisis yang digunakan pada penelitian ini adalah analisis regresi linear berganda. Teknik ini digunakan untuk mencari ada tidaknya pengaruh dan hubungan antara variabel bebas yaitu profitabilitas dan likuiditas terhadap variabel terikat struktur modal. Berikut merupakan ringkasan hasil output spss pengaruh profitabilitas $\left(\mathrm{X}_{1}\right)$ dan likuiditas $\left(\mathrm{X}_{2}\right)$ terhadap struktur modal $(\mathrm{Y})$ dapat dilihat pada Tabel 2.

Tabel 2. Ringkasan hasil output spss pengaruh profitabilitas (X1) dan likuiditas (X2) terhadap struktur modal (Y)

\begin{tabular}{lcccc}
\hline \multicolumn{1}{c}{ Parameter } & Nilai & P-value & a & Keputusan \\
\hline $\mathrm{Ryx}_{1} \mathrm{x}_{2}$ & 0,870 & 0,00 & 0,05 & Menolak $\mathrm{H}_{0}$ \\
\hline $\mathrm{R}^{2} \mathrm{yx}_{1} \mathrm{x}_{2}$ & 0,757 & 0,00 & 0,05 & Menolak $\mathrm{H}_{0}$ \\
\hline$\varepsilon$ & 0,243 & - & - & - \\
\hline $\mathrm{Pyx}_{1}$ & $-0,315$ & 0,039 & 0,05 & Menolak $\mathrm{H}_{0}$ \\
\hline $\mathrm{Py}^{2} \mathrm{x}_{1}$ & 0,099 & - & - & - \\
\hline $\mathrm{Pyx}_{2}$ & $-0,441$ & 0,003 & 0,05 & ${\text { Menolak } \mathrm{H}_{0}}^{2}$ \\
\hline $\mathrm{Py}^{2} \mathrm{x}_{2}$ & 0,194 & - & - & - \\
\hline
\end{tabular}

Berdasarkan tabel 2 menunjukkan bahwa secara simultan variabel bebas yaitu profitabilitaskdanklikuiditaskberpengaruh signifikan terhadap struktur modal pada perusahaan retail trade yang terdaftar di Bursa Efek Indonesia. Hal ini ditunjukkan dengan pvalue Ryx $1 \times 2=0,000<\alpha=0,05$. Besar pengaruh secara bersamaan dari profitabilitas dan likuditas terhadap struktur modal adalah sebesar 0,870 atau $87 \%$. Hal tersebut berarti bahwa dalam penelitian ini profitabilitaskdanklikuditasLberpengaruh terhadapkstruktur modal sebesar 0,757 atau 75,7\%, sedangkan Besar sumbangan pengaruh lain sebesar 0,243 atau $24,3 \%$

Berdasarkan tabel diatas menunjukkan bahwa secara parsial variabel profitabilitaskterhadap struktur modal sebesar $-0,315$ atau $-31,5 \%$ dan besar sumbangan pengaruh sebesar 0,099 atau 9,9\%. Besar p-value Pyx1 $=0,039<\alpha=0,05$ yang berarti 
adakpengaruhknegatif signifikan dari profitabilitaskterhadapkstruktur modal pada perusahan retail trade yang terdaftar di Bursa Efek Indonesia.

Berdasarkan tabel diatas menunjukkan bahwa secara parsial variabel klikuiditas terhadap struktur modal sebesar -0441 atau $-44,1 \%$ dan besar sumbangan pengaruh sebesar 0,194 atau 19,4\%. Besarnya p-value Pyx2 $=0,003<\alpha=0,05$ yang berarti bahwaiadaipengaruh positif signifikan dari likuditas terhadapl struktur modal pada perusahan retail trade yang terdaftar di Bursa Efek Indonesia.

$$
\varepsilon=0,243
$$

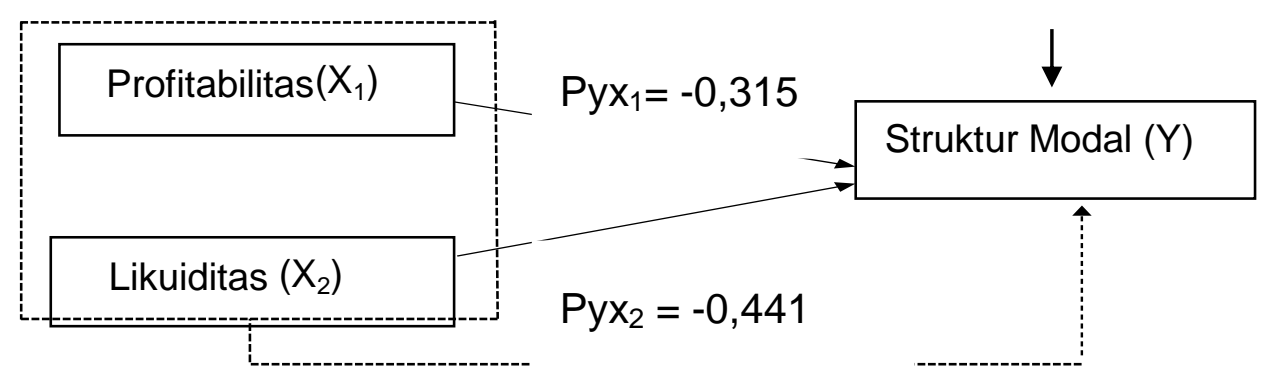

$$
\operatorname{Ryx}_{1} x_{2}=0,757
$$

Gambar 1. Struktur Hubungan Profitabilitas $\left(\mathrm{X}_{1}\right)$, Likuiditas $\left(\mathrm{X}_{2}\right)$ Terhadap Struktur Modal

Berdasarkan hasil penelitian menunjukkan ada pengaruh simultan $\mathrm{X}_{1}$ dan $\mathrm{X}_{2}$ terhadap Y pada perusahaan Retail Trade yang terdaftar di BEI tahun 2017 - 2018. Struktur modal merupakan cerminan dari baik tidaknya keadaan keuangan didalam sebuah perusahaan, sehingga struktur modal sangat dibutuhkan dalam meningkatkan suatu kegiatan operasional perusahaan untuk menilai keadaan perusahaan. Dalam hal ini penyusunan struktur modal menyesuaikan dengan kondisi perusahaan, apakah utang perusahaan dalam kondisi yang menyebabkan perusahaan mengalami kekurangan pendanaan atau kondisi profit perusahaan yang sedang dalam keadaan yang sangat baik.

Kondisi ini sesuai dengan pendapat dari Myers (1984) perusahaan yang memiliki laba yang tinggi justru memiliki tingkat hutang yang lebih kecil, hal ini disebabkan karena pihak perusahaan yang memiliki tingkat keuntungan yang tinggi cenderung memiliki sumber dana internal yang besar untuk mendanai suatu perusahaan. Hasil penelitian ini mendukung penelitian yang dilakukan oleh Wicaksono (2017).

Hasil penelitian ini menunjukkan ada pengaruh negatif dan signifikan $\mathrm{X}_{1}$ terhadap $\mathrm{Y}$ pada perusahaan Retail Trade yang terdaftar di BEI tahun 2017 - 2018. Profitabilitas kesanggupan sebuah usaha dalam mendapatkan laba dan memberikan tingkat efektivitas manajemen perusahaan yang akan ditunjukkan dari keuntunga bersih yang didapatkan serta berkaitan dengan penjualan, asset atau modal.

Kondisi ini sesuai dengan pendapat dari Brigham dan Houston (2006: 43), Menyatakan sebuah Perusahaan yang mempunyai sebuah tingkat pengembalian tinggi akan mempergunakan utang yang relatif sedikit. Perusahaan yang memiliki profitabilitas tinggi tidak perlu menggunakan dana eksternal karena dari laba yang tinggi tersebut perusahaan dapat membiayai operasional perusahaannya. Hasil penelitian ini mendukung penelitian yang dilakukan oleh Deviani dan Sudjarni (2018) dan penelitian yang dilakukan oleh Pertiwi dan Darmayanti (2018).

Hasil penelitian ini menunjukkan ada pengaruh negatif dan signifikan $\mathrm{X}_{2}$ terhadap $\mathrm{Y}$ pada Perusahaan Retail Trade yang terdaftar di BEI tahun 2017 - 2018. Likuiditas adalah 
likuiditas merupakan Rasio yang menilai sebuah kesanggupan likuiditas jangka pendek perusahaan dengan melihat aktiva lancar perusahaan relatif terhadap utang lancer.

Kondisi ini sesuai dengan pendapat dari Kasmir (2010: 110) Rasio likuiditas yang tinggi akan diikuti dengan utang yang rendah disebabkan oleh aktiva lancar pada perusahaan nantinya dapat memenuhi seluruh utang jangka pendek. Hasil penelitian ini mendukung penelitian yang dilakukan Watung (2016) dan Eviani (2015)

\section{Simpulan dan Saran}

Berdasarkan hasil uji statistik dan hipotesis serta pembahasan yang telah dilakukan dapat ditarik simpulan sebagai berikut. (1) X1 dan X2 berpengaruh signifikan secara bersama-sama Y pada perusahaan retail trade yang terdaftar di BEI tahun 2017-2018. Hal ini berarti X1 dan X2 secara bersama-sama berperan dalam upaya untuk membentuk Y pada perusahaan retail trade (2) X1 berpengaruh negatif dan signifikan terhadap $Y$ pada perusahaan retail trade yang terdaftar di BEI tahun 2017-2018. Hal ini berarti X1 dapat meningkatkan $\mathrm{Y}$ pada perusahaan retail trade. (3) X2 berpengaruh negatif dan signifikan terhadap Y pada perusahaan retail trade yang terdaftar di BEI tahun 2017-2018. Hasil ini berarti X2 dapat meningkatkan Y pada perusahaan retail trade.

Berdasarkan hasil penelitian dan simpulan maka saran yang dapat disampaikan adalah sebagai berikut.(1) Bagi Perusahaan ,Penelitian ini diharapkan dapat memberikan informasi bagi pihak perusahaan dalam menilai tingkat kesehatan. (2) Bagi Investor, Penelitian ini diharapkan dapat digunakan sebagai tambahan informasi dan referensi mengenai keputusan investasi seorang investor sebelum menanamkan modalnya pada suatu perusahaan. Hal tersebut dapat dilakukan dengan menganalisis secara mendalam mengenai struktur modal perusahaan. Hasil penelitian ini menyatakan bahwa terdapat dua aspek penting yang dapat mempengaruhi struktur modal yaitu perputaran profitabiltas dan likuiditas. Oleh karena itu, investor diharapkan memperhatikan profitabilitas dan likuiditas, sehingga dapat memberikan keputusan investasi yang paling tepat. (3) Bagi Peneliti Selanjutnya. penelitian selanjutnya disarankan untuk dapat mengambangkan penelitian ini dengan menggunakan subjek penelitian yang luas. Selain itu, diharapkan dapat mengembangkan penelitian ini lebih lanjut dengan menambah variabel lain yang dapat mempengaruhi struktur modal.

\section{Daftar Pustaka}

Adiguna dan Sampurno. 2018. “Analisis Faktor-Faktor Yang Mempengaruhi Struktur Modal (Studi Kasus Pada Perusahaan Makanan Dan Minuman Yang Terdaftar Di Bei Periode 2012 - 2016)". Diponegoro Journal Ofmanagement, Volume 7, Nomor 2.

Brigham, Eugene., dan Houston Joel, F. 2006. Dasar-Dasar Manajemen Keuangan. Edisi kesepuluh. Jilid kedua. Jakarta: Salemba Empat.

Brigham, Eugene., dan Houston Joel, F. 2011. Dasar-Dasar Manajemen Keuangan. Edisi kesebelas. Jilid kedua. Jakarta: Salemba Empat.

Dahlena. 2017. "Pengaruh Likuiditas, Risiko Bisnis dan Profitabilitas Terhadap Struktur Modal”. Jurnal Riset Akuntansi \& Bisnis, Vol. 17 Nomor. 2.

Danang, Sunyoto. (2013). Metodologi Penelitian Akuntansi. Bandung: PT Refika Aditama Anggota Ikapi.

Darsono. 2017. "Faktor-Faktor yang Mempengaruhi Struktur Modal”. E-Jurnal Undip, Vol. 6, Nomor.3.

Deviani, Sudjarni. 2018. "Pengaruh Tingkat Pertumbuhan, Struktur Aktiva, Profitabilitas, dan Likuiditas Terhadap Struktur Modal”. E-jurnal Manajemen Unud, Vol. 7, Nomor. 3.

Eviani, Dewi. 2015. "Pengaruh Struktur Aktiva, Pertumbuhan Penjualan, Dividend Payout 
Ratio, Likuiditas dan Profitabilitas Terhadap Struktur Modal". Jurnal Akuntansi dan SistemTeknologi Informasi, Vol.11, Nomor. 2.

Fahmi, Irham. 2011. Analisis Laporan Kuangan. Bandung: Alfabeta.

Fahmi. 2016. Pengantar Manajemen Keuangan. Bandung: Alfabeta.

Ghozali, Imam. 2006. Aplikasi Analisis Multivariate Dengan Program SPSS. Semarang: Badan Penerbit Universitas Diponegoro.

Hanafi, Halim. 2014. Analisis Laporan Keuangan. Edisi keempat. Yogyakarta: UPP STIM YKPN.

Jusuf, Haryono.2011. Dasar-Dasar Akuntansi. Edisi ketujuh. Yogyakarta: STIE YKPN.

Kasmir. 2010. Pengantar Manajemen Keuangan. Jakarta: Kencana.

Kasmir. 2013. Analisis Laporan Keuangan. Jakarta: PT Raja GrafindoPersada.

Kasmir. 2015. Manajemen Perbankan. Jakarta: PT Raja Grafindo Persada.

Kodrat, David Sukardi dan Kurniawan Indonanjaya. 2010. Manajemen Investasi Pendekatan Teknikal dan Fundamental untuk Analisa Saham. Yogyakarta: Graha Ilmu.

Maulina dkk. 2018. "Pengaruh Faktor-Faktor Penentu Struktur Modal Terhadap Struktur Modal". Jurnal Administrasi Binis, Vol. 58, Nomor 1 (hlm. 161-163).

Pertiwi, Darmayanti. 2018. "Pengaruh Profitabilitas, Likuiditas, Struktur Aktiva, dan Kebijakan Dividen Terhadap Struktur Modal". E-jurnal Manajemen Unud, Vol. 7, Nomor. 6.

Riyanto, Bambang. 2001. Dasar-dasar Pembelanjaan Perusahaan. Edisi Empat. Cetakan Ketujuh. Yogyakarta: BPFE UGM.

Riyanto, Bambang 2011. Dasar-Dasar Pembelajaran Perusahaan. Edisi Keempat Cetakan Keenam. Yogyakarta: BPFE.

Suhardi dan Afrizal. 2019. "Bagaimana Pecking-Order Theory Menjelaskan Struktur Permodalan Bank Di Indonesia?”. Jurnal Ekonomi dan Sosial, Volume 10, Nomor 01.

Suharyadi dan Purwanto. 2011. Statistik untuk Ekonomi dan Keuangan Modern. Edisi 2. Jakarta: Salemba Empat

Watung. 2016. "Pengaruh Rasio Likuiditas, Aktivitas, Profitabilitas, dan Struktur Aktiva Terhadap Struktur Modal pada Perusahaan Industri Barang Konsumsi di Bursa Efek Indonesia”. Jurnal EMBA. Vol.4, Nomor. 2 (hlm. 733-735).

Wiagustini, N.L.P. 2010. Dasar-dasar Manajemen Keuangan. Denpasar: Udayana University Press.

Wicaksono. 2017. "Pengaruh Profitabilitas, Likuiditas, Dan Struktur Aktiva Terhadap Struktur Modal”. Simki-Econimic. Vol. 01, Nomor. 12 (hlm.12). 